Utah State University

DigitalCommons@USU

$10-1987$

\title{
Clonal Foraging in Perennial Wheatgrasses: a Strategy for Exploiting Patchy Soil Nutrients
}

L. D. Humphrey

D. A. Pyke

Follow this and additional works at: https://digitalcommons.usu.edu/aspen_bib

Part of the Agriculture Commons, Ecology and Evolutionary Biology Commons, Forest Sciences Commons, Genetics and Genomics Commons, and the Plant Sciences Commons

\section{Recommended Citation}

Humphrey, L.D., D.A. Pyke. 1997. Clonal Foraging in Perennial Wheatgrasses: a Strategy for Exploiting Patchy Soil Nutrients. Journal of Ecology 85(5): 601-610.

This Article is brought to you for free and open access by the Aspen Research at DigitalCommons@USU. It has been accepted for inclusion in Aspen Bibliography by an authorized administrator of DigitalCommons@USU. For more information, please contact

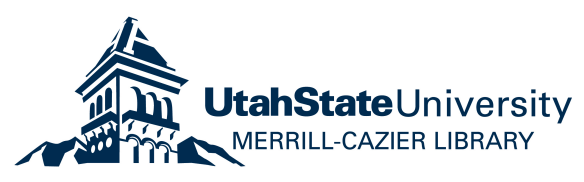




\section{British Ecological Society}

\section{WILEY}

Clonal Foraging in Perennial Wheatgrasses: A Strategy for Exploiting Patchy Soil

Nutrients

Author(s): L. David Humphrey and David A. Pyke

Source: Journal of Ecology, Vol. 85, No. 5 (Oct., 1997), pp. 601-610

Published by: British Ecological Society

Stable URL: http://www.jstor.org/stable/2960531

Accessed: 16-11-2016 21:17 UTC

JSTOR is a not-for-profit service that helps scholars, researchers, and students discover, use, and build upon a wide range of content in a trusted digital archive. We use information technology and tools to increase productivity and facilitate new forms of scholarship. For more information about JSTOR, please contact support@jstor.org.

Your use of the JSTOR archive indicates your acceptance of the Terms \& Conditions of Use, available at http://about.jstor.org/terms

British Ecological Society, Wiley are collaborating with JSTOR to digitize, preserve and extend access to Journal of Ecology 
Journal of

Ecology 1997, 85, 601-610

\title{
Clonal foraging in perennial wheatgrasses: a strategy for exploiting patchy soil nutrients
}

\author{
L. DAVID HUMPHREY and DAVID A. PYKE* \\ Department of Rangeland Resources and the Ecology Center, Utah State University, Logan, Utah 84322-5230, \\ USA, and *Forest and Rangeland Ecosystem Science Center, Biological Resources Division, US Geological \\ Survey, 3200 SW Jefferson Way, Corvallis, Oregon 97331, USA
}

\begin{abstract}
Summary
1 Foraging by means of plasticity in placement of tillers in response to low- and highnutrient patches was examined in the rhizomatous wheatgrass Elymus lanceolatus ssp. lanceolatus. Its ability to exploit soil nutrient patches was compared to that of the closely related but caespitose E. lanceolatus ssp. wawawaiensis.

2 Clones of 14 genets of each taxon were planted in boxes consisting of two $30 \times 30 \mathrm{~cm}$ cells: the 'origin cell' where clones were planted, and the adjacent 'destination cell', with each cell containing soil with either low or high levels of nutrients.

3 The rhizomatous taxon, which can produce intravaginal, short-rhizome and longrhizome tillers, preferentially produced short-rhizome and intravaginal tillers in highnutrient destination cells. Effects of nutrient status of the origin cell as well as of the destination cell on total tiller numbers indicated clonal integration, yet tiller placement responded to local conditions.

4 Roots of both taxa accessed nutrients in destination cells (the caespitose subspecies by root growth only), and above-ground biomass of both taxa increased to a similar extent with high-nutrient destination cells. With the patch sizes used in this experiment, root growth was as important as ramet placement in exploiting nutrients in destination cells.
\end{abstract}

5 There was no relationship between degree of plasticity in ramet placement and biomass of the clone when high-nutrient destination cells were present.

Keywords: Elymus lanceolatus, genetic differences, morphological plasticity, nitrogen patches

Journal of Ecology (1997) 85, 601-610

\section{Introduction}

Foraging has been defined as 'the processes whereby an organism searches, or ramifies within its habitat, which enhance its acquisition of essential resources' (Hutchings \& de Kroon 1994). In plants, foraging may be achieved by morphological responses of shoots, rhizomes, stolons or roots to patchy resources and, in a broader sense, many types of responses to patches (including no response) can be considered as foraging (de Kroon \& Hutchings 1995). Physiological responses to resource patches may also be considered a means of foraging (Jackson, Manwaring \& Caldwell 1990; Hutchings \& de Kroon 1994). Foraging responses for plants or animals have been more rigorously defined as responses that: (i) occur before resource uptake; (ii) modify the degree of uptake; and (iii) can be varied by the foraging organism (Kelly 1990). Morphological responses of above-ground parts to light patches, triggered by responses to the red/far-red ratio (Ballaré, Scopel \& Sanchez 1990), may satisfy all three of these requirements (Hutchings $\&$ de Kroon 1994). Most foraging responses to soil nutrient patches, however, are probably hormonally mediated responses to resource uptake, and therefore occur shortly after patches are encountered, rather than before resource uptake (Hillman 1984; Salisbury \& Marinos 1985; Hutchings \& Mogie 1990; Hutchings \& de Kroon 1994; Voesenek \& Blom 1996). However, this distinction may be unimportant (e.g. Pyke 1978; Hutchings \& de Kroon 1994).

One widely recognized means of foraging in clonal plants is by morphological plasticity in ramet placement in response to resource patches. Decreased spacing between parent and daughter ramets or increased rhizome branching within resource-rich patches enables plants to exploit resource-rich patches effectively and pass through poor patches with lower investment (Cook 1983; Salzman 1985; Slade \& Hut- 
chings 1987a; Sutherland \& Stillman 1988; de Kroon \& Knops 1990).

Plastic foraging responses are examples of phenotypic plasticity. Genotypic differences in the degree of plasticity have been found for many plant traits (e.g. Bradshaw 1965; Jain 1978; Taylor \& Aarssen 1988; Thompson, McNeilly \& Gray 1991; Cheplick 1995). Plasticity, which can be an important adaptation to variable or unpredictable environments (Bradshaw 1965; Jain 1978; Hume \& Cavers 1982), can be subject to natural selection (Bradshaw 1965; Schlichting 1986; Pigliucci 1996). The fitness advantage of a plastic response of orthotropic shoots to light was demonstrated by Schmitt, McCormac \& Smith (1995). Others have shown that clonal plants produced greater biomass in patchy than in uniform habitats, but due mainly to plastic root/shoot allocation (Birch \& Hutchings 1994), or to clonal integration and resource transport (Stuefer, During \& de Kroon 1994; Wijesinghe \& Handel 1994). Cheplick (1995) found genetic differences in the amount of rhizome production in response to nutrient levels. However, few have tested for genetic differences in the degree of plasticity in the ramet placement response or related these differences to difference in fitness in patchy habitats, in order to determine if this plasticity is adaptive (sensu Thompson 1991).

We investigated the existence, and advantages to the genet, of foraging by plasticity in ramet placement under conditions of patchy soil nutrients for Elymus lanceolatus ssp. lanceolatus (Scribner \& J. G. Smith) Gould (thickspike wheatgrass), a rhizomatous perennial wheatgrass native to the western United States. Its ability to exploit patchy soil nutrients was compared with that of a closely related native grass, proposed name E. lanceolatus ssp. wawawaiensis (Scribner \& Gould) J. R. Carlson \& D. R. Dewey (Snake River wheatgrass), which produces all tillers intravaginally (from within the leaf sheaths of previous tillers) and therefore cannot exhibit plasticity in tiller placement. However, root proliferation in nutrientrich patches can be another effective means of foraging for soil resources (Drew \& Saker 1978; Crick \& Grime 1987; Eissenstat \& Caldwell 1988; Jackson \& Caldwell 1989, 1996). Therefore, both the caespitose and the rhizomatous subspecies may be able to exploit nutrient-rich patches, but by different mechanisms. Both wheatgrass taxa occur in sagebrush steppe, where patchiness of soil resources is important (Jackson \& Caldwell 1993), but Snake River usually occurs on shallow soils and is considered drought tolerant, while thickspike often occurs on deeper, sandy soils (J. R. Carlson et al., unpublished data).

We addressed hypotheses concerning: (i) the degree of plasticity exhibited by the rhizomatous taxon in ramet placement in response to nutrient patches; (ii) the ability of roots of both taxa to access patchy soil nutrients; (iii) the total genet above-ground biomass of the rhizomatous taxon, thickspike, compared to that of the caespitose taxon, Snake River, under patchy soil nutrient conditions; and (iv) whether genets that differ in degree of ramet placement response have different total above-ground biomass.

\section{Methods}

Plants were grown in patchy nutrient environments consisting of two cells: the 'origin cell' where the plant originated; and the 'destination cell', into which the plant could grow; each of which could be of either low or high nutrient status. The overall experimental design involved a factorial analysis of variance (ANOVA) with the factors origin and destination, each with two nutrient levels, taxon (two levels, thickspike and Snake River), and genet (nested within taxon), in two replications. Origin, destination and taxon were fixed variables; genet was a random variable. There were 14 levels of genet: each of 14 genets of the two taxa was divided into eight clones of essentially equal size and morphology. Such ANOVA designs are effective ways of comparing plastic responses of different genotypes to environments. A significant 'environment' response indicates that some genotypes respond differently to different environments. A significant 'genotype by environment' interaction indicates that genotypes differ in the plasticity they display, and represents the heritable component of phenotypic plasticity (Schlichting 1986; Thompson 1991; Bell \& Lechowicz 1994).

Genets of thickspike produce relatively long rhizomes, commonly over $15 \mathrm{~cm}$, that produce isolated tillers, with other tillers arising from rhizomes a few centimetres long or arising intravaginally. Origin and destination cells were each $30 \mathrm{~cm} \times 30 \mathrm{~cm} \times 60 \mathrm{~cm}$ deep, with the clone planted in the centre of the origin cell. At this scale, we considered that thickspike's variation in rhizome lengths would allow it to access high-nutrient destination cells by rhizome growth and concentrate tillers within them, if it preferentially produced shorter rhizomes within them. Also, there is considerable patchiness of soil resources at this scale in the sagebrush steppe environment where these taxa occur (Jackson \& Caldwell 1993). Since it lacks rhizomes, Snake River cannot respond to patchiness by plasticity in ramet placement, but could access destination cells by root growth, and may be able to exploit them through plasticity in root growth.

Each plot consisted of a pair of cells that were constructed of plywood, with a plywood bottom. Removable walls that divided paired cells consisted of $6 \mathrm{~mm}(0.25 \mathrm{inch})$-thick plywood fitted into slots on the interior of the walls. Boxes were located at the Utah State University Ecology Centre Complex in Logan (Utah, USA), and filled with soil in October 1991 before being allowed to settle over winter. The soil used was a deposit of pluvial Lake Bonneville shoreline sediments, of very fine sandy loam texture, excavated from a pit $4.5 \mathrm{~km}$ south of Logan. It was 


\section{L.D. Humphrey \&} D.A. Pyke
Table 1 Nutrient analysis of very fine sandy loam used as growing medium in the experiment, based on two replicate samples of in situ material ( $\mathrm{pH} 7.9)$

\begin{tabular}{|c|c|c|c|c|c|c|c|c|}
\hline \multirow[b]{2}{*}{ Sample } & \multirow{2}{*}{$\begin{array}{l}\mathrm{NO}_{3}-\mathrm{N} \\
\left(\mathrm{mg} \mathrm{kg}^{-1}\right)\end{array}$} & \multirow{2}{*}{$\begin{array}{l}\mathrm{P} \\
\left(\mathrm{mg} \mathrm{kg}^{-1}\right)\end{array}$} & \multirow{2}{*}{$\begin{array}{l}\mathrm{K} \\
\left(\mathrm{mg} \mathrm{kg}^{-1}\right)\end{array}$} & \multirow{2}{*}{$\begin{array}{l}\text { Organic C } \\
(\%)\end{array}$} & $\mathrm{Ca}$ & $\mathrm{Mg}$ & $\mathrm{Na}$ & $\mathrm{K}$ \\
\hline & & & & & \multicolumn{4}{|c|}{ (mg L ${ }^{-1} \mathrm{H}_{2} \mathrm{O}$ solution) } \\
\hline No.1 & 2.0 & 3.3 & 170 & 0.20 & 21.1 & 11.3 & 51.7 & 14.0 \\
\hline No.2 & 5.8 & 2.6 & 132 & 0.22 & 52.5 & 35.4 & 110.9 & 18.0 \\
\hline
\end{tabular}

chosen because nitrogen and phosphorus contents were very low. However, potassium, other cations, and $\mathrm{pH}$ were high (Table 1). Low-nutrient cells received no additional nutrients. Each high-nutrient cell received $3.88 \mathrm{~g}$ of $\mathrm{K}_{2} \mathrm{HPO}_{4}$ and $1.93 \mathrm{~g} \mathrm{NH} \mathrm{NO}_{3}$ applied in $500 \mathrm{ml}$ of aqueous solution. These applications were estimated to produce nutrient levels at or above levels recommended for hay or turf (Utah State University Soil Analysis Laboratory, personal communication). To extend the time when nitrogen was available under the high-nutrient conditions, a slow-release nitrogen fertilizer, sulphur-coated urea (which consists of $33 \%$ soluble nitrogen), was applied to the surface of high-nutrient cells at a rate of $3.27 \mathrm{~g}$ per cell. Genets were arbitrarily selected from a mixed stand of the two taxa established for another experiment, from one seed accession of each taxon obtained from the USA Natural Resources Conservation Service (Plant Materials Centre, Aberdeen, Idaho and Pullman, Washington, USA). Genets were divided and clones of 15-25 tillers each were planted into origin cells on 19-29 March 1992. On 27-30 April, nutrient solution was added to high-nutrient cells with the low-nutrient cells receiving $500 \mathrm{ml}$ of water. Sulphur-coated urea was added on 5-6 May 1992. Divider walls remained in place between cell pairs until 23-25 May 1992. During this time, cells with plants were watered in amounts sufficient to promote establishment of the plants.

To limit diffusion of nutrients between high- and low-nutrient cells and to preserve the patchy nutrient conditions after dividers were removed, surface watering was limited, and plots were sheltered from rain by a temporary structure covered with clear polyethylene film with ventilation openings along the base and top. Water was added using a PVC pipe that was inserted into the side of each cell $5 \mathrm{~cm}$ from the bottom and with its opening in the centre of the cell. This bottom watering provided water to the plants while causing less diffusion of soil nutrients, as these were primarily in the upper portion of the soil. At first, plots were watered with 21 per cell below-ground at 5 -week intervals, and $500 \mathrm{ml}$ per cell on the surface at 2-3-week intervals. Because the effectiveness of below-ground watering was variable, watering by this method was reduced between August and November, and surface watering of $750 \mathrm{ml}$ per plot was applied every 1-2 weeks.

After establishment in spring 1992, the experiment continued until summer senescence at the end of the second growing season (July 1993). In February 1993, the rain shelter was removed, because the conditions of the experiment in 1992 had substantially limited plant growth.

Soil samples (about $200 \mathrm{~cm}^{3}$ ) were taken on 2 June, 17 July and 23 September 1992, and on 21 January and 20 July 1993 to monitor nutrient depletion in high-nutrient cells and possible diffusion of nutrients into low-nutrient cells. At each sample date, eight plots were randomly chosen, without replacement, from plots that had one low-nutrient and one highnutrient cell. Samples were taken from the top $10 \mathrm{~cm}$ at three locations: in the low-nutrient cell $10 \mathrm{~cm}$ and $5 \mathrm{~cm}$ from the border between the two cells, and in the high-nutrient cell $5 \mathrm{~cm}$ from the border, and were analysed for available nitrogen and available phosphorus by the Utah State University Soil Analysis Laboratory (Logan, Utah). In September 1992 and again in July 1993, in addition to the samples taken from plots with high- and low-nutrient cells, soil samples were also taken from eight plots where both cells were low-nutrient, to see if diffusion had increased nutrient levels of low-nutrient cells attached to highnutrient cells relative to nutrient levels of low-nutrient cells in plots where both cells were low-nutrient.

Destination cells were excavated in August 1993, and tiller numbers and lengths of rhizomes giving rise to each tiller were recorded. Although data were obtained from a single destructive harvest, tillers and rhizomes produced from autumn 1992 to July 1993 were intact and were included in the data. As autumn tillers survive winter, this period is considered as one growth cycle. Few rhizomes had accessed destination cells by autumn 1992. (A small proportion of rhizomes encountered the wall. These variously turned, stopped growing, produced branch rhizomes, or produced a tiller. Only three rhizomes exited boxes.)

At the time rhizomes were excavated, root biomass for each destination cell was obtained by sieving roots from soil using a 3-mm mesh sieve. Only 10 of the 14 genets were used in analysis of root biomass to preserve a balanced design (genets for which one plot had been omitted because of disturbance to the plot were completely omitted from the analyses; other randomly selected genets were omitted to retain equal numbers of genets per taxon). In the thickspike plots, roots were separated into those arising from rhizomes that entered the destination cell and those arising from 
roots in the origin cell that grew into the destination cell. We did this by excavating the root system in the destination cell intact, so that physical connections of roots would identify their origins. However, some broken fine roots remained whose source could not be identified. Roots were washed, oven dried at $70^{\circ} \mathrm{C}$ and weighed. Sieving in this way is not a rigorous method of obtaining root biomass (Bohm 1979; Caldwell \& Virginia 1989), but it should be acceptable for making comparisons of root biomass between plots. To obtain an estimate of root biomass not recovered, subsamples of sieved soil $(22 \%$ of the total sample) from six plots were processed through a hydropneumatic elutriation system (Smucker, McBurney \& Srivastava 1982).

Above-ground biomass was clipped at $5 \mathrm{~cm}$ height at summer senescence in July 1993, oven-dried at $70^{\circ} \mathrm{C}$ for $48 \mathrm{~h}$, and weighed.

Greater branching intensity in high-nutrient patches can be a direct result of more growth, but reduced rhizome length between parent and daughter ramets is a morphological response to patch quality that results in more effective exploitation of patches. Thus, the appropriate test for plasticity in ramet placement should be the response of spacer lengths (Hutchings $\&$ de Kroon 1994; Cain 1994). Therefore, to address the hypothesis on plasticity in tiller placement in thickspike (adapting terms of Lovett Doust 1981), tillers in the destination cell were divided into (i) phalanx tillers - intravaginal tillers, and those arising from short rhizomes $(\leqslant 3 \mathrm{~cm})$ and thus forming bunchgrass-like clumps; and (ii) guerilla tillers - those with rhizomes $>3 \mathrm{~cm}$. The null hypothesis stated that proportion of tillers that were phalanx would not differ with nutrient status of the destination cell (the test for plasticity in ramet placement), nutrient status of origin, or between genets.

Many plots with low-nutrient origin cells produced no tillers in the destination cell, and so provided no meaningful data on the proportion of tillers that were phalanx. Only seven of the 28 plots with low nutrient levels in both origin and destination cells (14 genets in two replicates) and 19 of 28 with low-nutrient origin and high-nutrient destination produced tillers in destination cells. Therefore, effects of destination cell and genet were analysed using only the plots with highnutrient origin cells. Effects of origin were addressed in a secondary analysis.

The second null hypothesis stated that root biomass in the destination cell would not differ between taxa (indicating that roots of the rhizomatous and the caespitose taxa exploited high-nutrient destination cells equally), nutrient status of destination or origin cell, or between genets nested within taxon. The third null hypothesis stated that total aboveground biomass of the clone would not differ with taxon, nutrient status of origin or destination cells and genets nested in taxon. Of particular interest was the destination-by-taxon interaction, indicating differences between taxa in ability to benefit from high-nutrient destination cells. The second and third hypotheses were tested using the entire factorial design: taxon, origin, destination and genets within taxon. The first three hypotheses were tested using the GLM Procedure (SAS 1988).

For the fourth hypothesis, concerning the fitness advantage of plasticity in ramet placement in thickspike, we used above-ground biomass as a fitnessrelated trait. Biomass is often strongly correlated with survival and reproduction, and should be a good indication of fitness (Schmitt et al. 1995). Degree of plasticity in ramet placement was calculated for each genet as the proportion of tillers that were phalanx in the high-nutrient destination cell, divided by the sum of the proportions that were phalanx in high- and lownutrient destination cells. Thus, destination was no longer a factor in the analysis. As only plots with high-nutrient origin cells were used to compare genets in the analysis of proportion of tillers that were phalanx, the null hypothesis stated that total aboveground biomass of the clone, when high-nutrient destination cells were available, would not differ with the genet's degree of plasticity in ramet placement, and was tested with linear regression (REG Procedure; SAS 1988).

\section{Results}

\section{SOIL NUTRIENTS}

Concentrations of nitrogen and phosphorus in lownutrient cells were at levels considered low for sagebrush steppe soils $\left(<5 \mathrm{mg} \mathrm{kg}^{-1}\right.$ of available nitrogen and $<10 \mathrm{mg} \mathrm{kg}^{-1}$ phosphate; Jackson \& Caldwell 1991) throughout the experiment, except nitrogen slightly exceeded $5 \mathrm{mg} \mathrm{kg}^{-1}$ in September (Fig. 1). These nutrient levels apparently severely limited growth of the grasses in this experiment when both cells of the plot were at low nutrient levels. Nutrient levels in high-nutrient cells were usually an order of magnitude higher than in the adjacent low-nutrient cells (Fig. 1). By the end of the experiment nitrogen was depleted in both high- and low-nutrient cells (Fig. 1). Nitrogen depletion occurred during spring, when abundant plant growth occurred. Thus, plant responses are assumed to be responses to patches of low and high nitrogen and phosphorus. Nutrients diffusing from high-nutrient cells did not significantly increase nitrogen or phosphorus levels in low-nutrient cells, compared to plots in which both cells were lownutrient (data not shown).

\section{DISCRIMINATION BETWEEN LOW-AND HIGH-} NUTRIENT CELLS

A significantly greater proportion of tillers was phalanx in high-nutrient than in low-nutrient destination cells $(P<0.02$; Fig. 2$)$. Differences between genets 
L.D. Humphrey \& D.A. Pyke
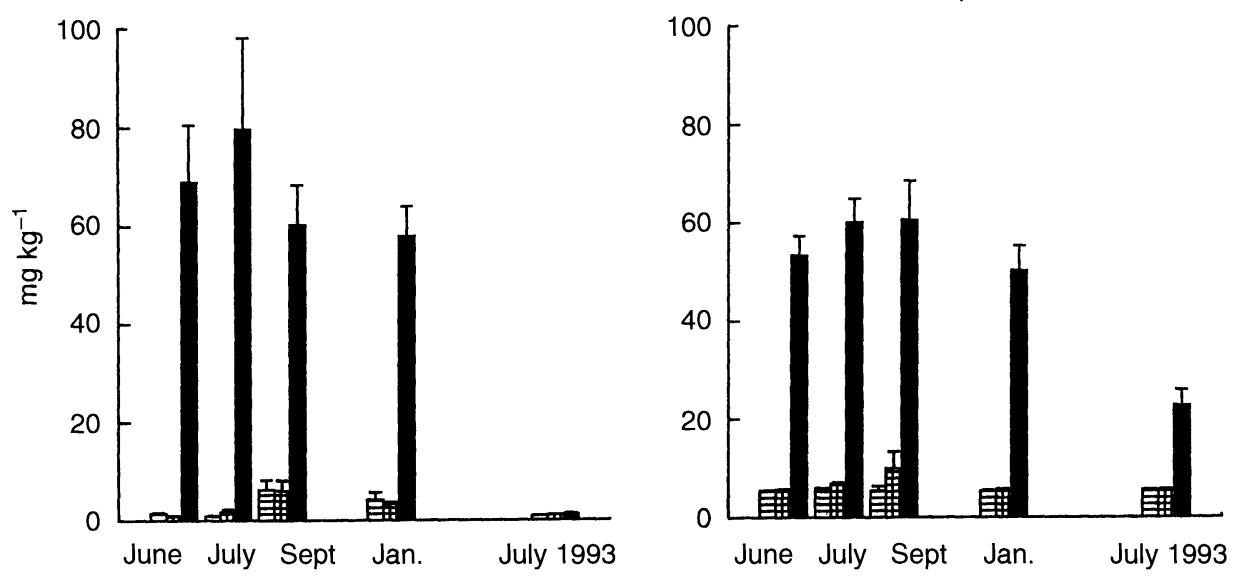

Fig. 1 Means and SE $(n=8)$ of soil nutrient concentrations in samples taken over the course of the experiment. Hatched bars are $10 \mathrm{~cm}$ into low-nutrient cells from the border between cells, cross-hatched bars are $5 \mathrm{~cm}$ into low-nutrient cells from the border, and solid bars represent $5 \mathrm{~cm}$ into high-nutrient cells from the border.

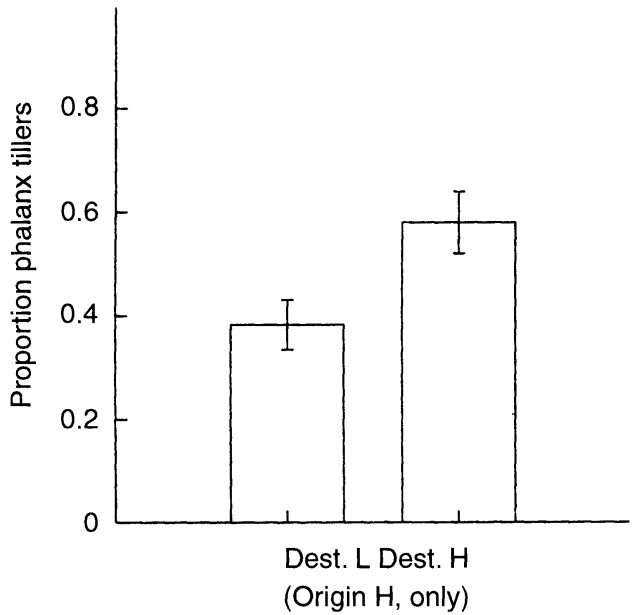

Fig. 2 Means and SE of the proportion of tillers in the destination cell that were phalanx for low- (L) and high-nutrient (H) destination (Dest.) cells (high-nutrient origin only; see text). The nutrient status of the destination cell was significant $(P<0.02)$; genet was not significant. In a secondary ANOVA with the factors origin and destination, destination was again significant $(P<0.03)$, but origin was not significant. Arcsin square root transformation of the proportional data was used in analyses.

and the destination-by-genets interaction were not significant, a result that is pertinent to the fourth hypothesis. In a secondary analysis, nutrient status of origin cells was not significant.

Nutrient status of both the origin and destination cells was highly significant in determining the number of all tillers in the destination cell $(P<0.0001$, $P<0.001$, respectively); their interaction was not significant (Fig. 3), and genets did not differ significantly. The number of all tillers in the destination cell was primarily a function of total nutrient availability, regardless of whether nutrients were in origin or destination cells (Fig. 3).

\section{(C) 1997 British}

Ecological Society, Journal of Ecology, 85, 601-610

\section{ROOTS EXPLOITING HIGH-NUTRIENT CELLS}

Snake River, the caespitose grass, had slightly higher root biomass in destination cells than thickspike,

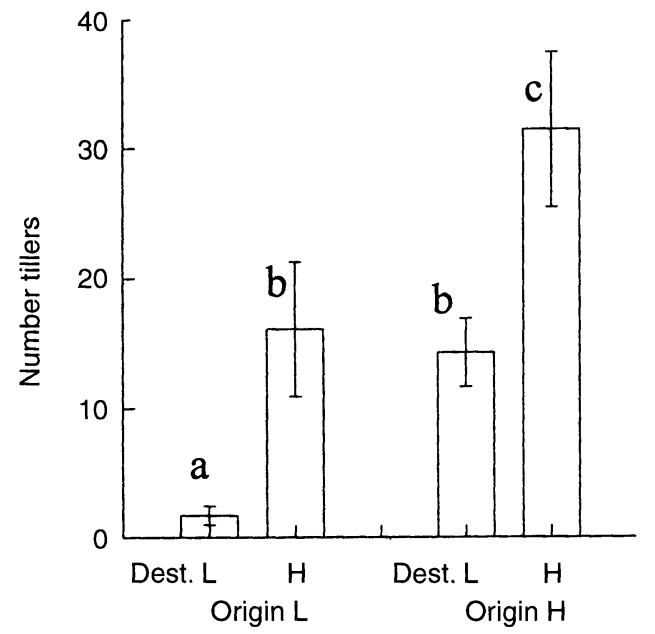

Fig. 3 Effects of nutrient status of origin and destination cells on means and SE for number of all tillers in the destination cell. Means with the same letter above them are not significantly different. Mean comparisons were done by $t$-test comparisons of LS means (least squares estimates of marginal means for unbalanced designs). Natural log transformation of number of tillers was used in the analyses.

regardless of nutrient status of origin and destination cells $(P<0.05$; Fig. 4). Origin, destination and their interaction were highly significant $(P<0.0001)$. Roots of both taxa invaded high-nutrient destination cells regardless of nutrient status of the origin cell. Many roots also invaded low-nutrient destination cells with high-nutrient origin cells, but invading roots were few when both origin and destination cells were low in nutrients (Fig. 4). Origin-by-taxon and destination-by-taxon interactions were not significant, indicating that each taxon responded similarly to nutrient status of each cell. Root biomass of genets also did not differ significantly.

Only about $35 \%$ of the root biomass in destination cells was identified as arising from rhizomes in the destination cell, or as arising from roots entering from the origin cell (Table 2a). Considering the large proportion of roots that were not identified as to source, 
Clonal foraging and patchy soil nutrients
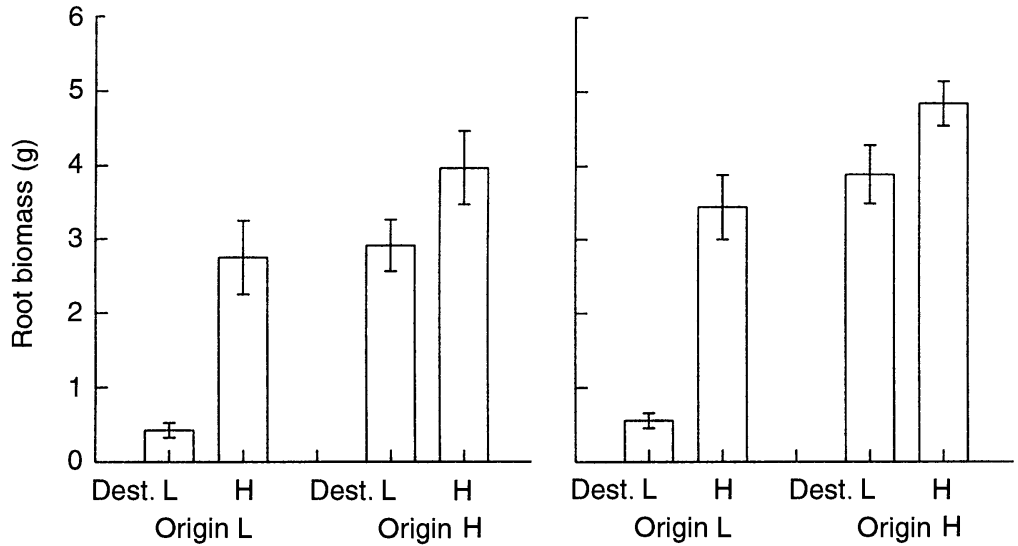

Fig. 4 Effects of nutrient status of origin and destination cells on root biomass (means and SE) in the destination cell for each taxon. Square root transformed root biomass was used in the analysis, because this transformation best satisfied the ANOVA assumption of a normal distribution.
Table 2 (a) Proportion of all roots of the rhizomatous taxon, thickspike, that could be identified as to their source (from rhizomes or from roots outside the destination cell), using corrected total root biomass based on estimates of proportion of root biomass not recovered by sieving. (b) Of those identified roots, the proportion that arose from rhizomes within the destination cell. For both (a) and (b), means and SE for each combination of origin and destination are presented

\section{Mean SE}

(a) Proportion of roots identified Origin Low - Destination Low Origin Low - Destination High $0.26 \quad 0.05$ Origin High - Destination Low Origin High - Destination High All plots (b) Proportion of roots that arose from rhizomes Origin Low - Destination Low $\quad 0.14$ Origin Low - Destination High $\quad 0.40$ Origin High - Destination Low $\quad 0.46$ 0.11 Origin High - Destination High

$0.66 \quad 0.10$

data on proportion of roots from rhizomes can only be considered as crude estimates. Nevertheless, about half of the identified roots arose from roots in the origin cell, except in plots with low levels of nutrients in both origin and destination cells, where the proportion from rhizomes was much lower (Table $2 b$ ). There is no reason to assume that fine roots were substantially more likely to break from roots from either source. Therefore, these data indicate that contributions of roots from both sources were important.
(Fig. 5). High-nutrient status in the origin cell resulted in greater above-ground biomass per plot regardless of the nutrient status of the destination cell or of taxon. Biomass was also greater with high-nutrient destination with both low- and high-nutrient origin, although the effect of destination was greater when origin cells were low in nutrients (Fig. 5). Genets differed in above-ground biomass within each taxon $(P<0.05)$, but their interactions were not significant.

Total above-ground biomass was also clipped in 1992. Biomass was lower overall in that year, and the effect of nutrient status of the destination cell was minor, indicating that most plants had not yet accessed the destination cells.

\section{BIOMASS OF GENETS DIFFERING IN FORAGING ABILITY}

The analysis of the first hypothesis indicated no genetic variation in degree of plasticity in tiller placement. No significant relationship was found between degree of foraging response and total above-ground biomass when high-nutrient destination cells were available (Fig. 6).

\section{Discussion}

\section{FORAGING RESPONSE}

Thickspike wheatgrass showed plasticity in tiller placement in response to nutrient patches. A greater proportion of phalanx tillers (intravaginal tillers and those arising from rhizomes $\leqslant 3 \mathrm{~cm}$ ) was produced in high-nutrient destination cells than in low-nutrient destination cells. This is a morphological response to nutrient patches that promotes more effective exploitation of patchy soil resources and is not a result of differences in amount of growth (sensu Hutchings \& de Kroon 1994; Cain 1994). This result is notable 


\section{L.D. Humphrey \&} D.A. Pyke

(C) 1997 British Ecological Society, Journal of Ecology, 85, 601-610
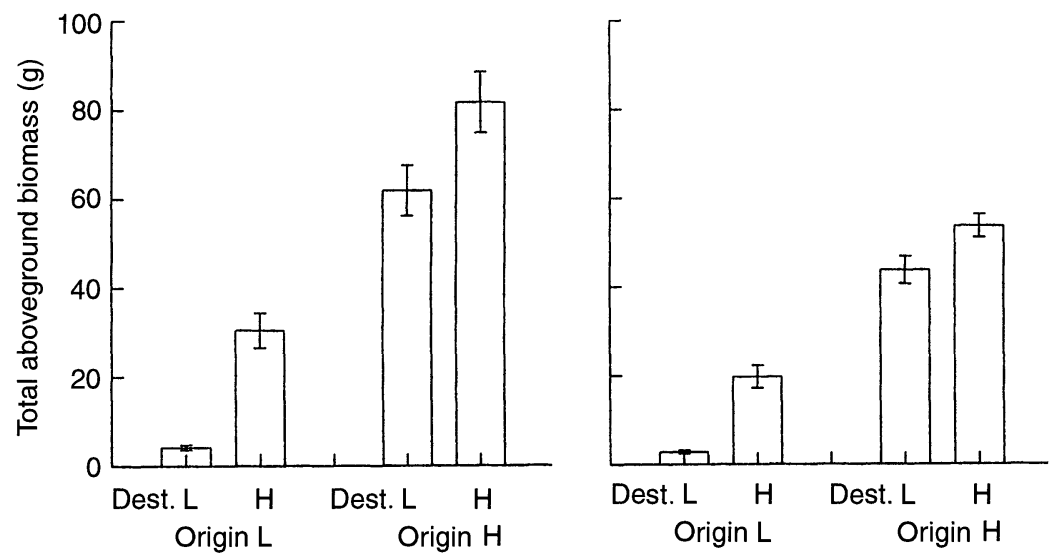

Fig. 5 Above-ground biomass (means and SE) for the entire plot in 1993. Origin, destination and their interaction were highly significant $(P<0.0001)$. The two levels of destination differed within both levels of origin $(P<0.0001, P<0.001$ in origin low and high, respectively, with the two taxa combined; based on $t$-test comparisons of LS means). Taxon and genet were also significant $(P<0.05$ for both). Square root biomass was used in the analysis, because this transformation best satisfied the ANOVA assumption of a normal distribution.

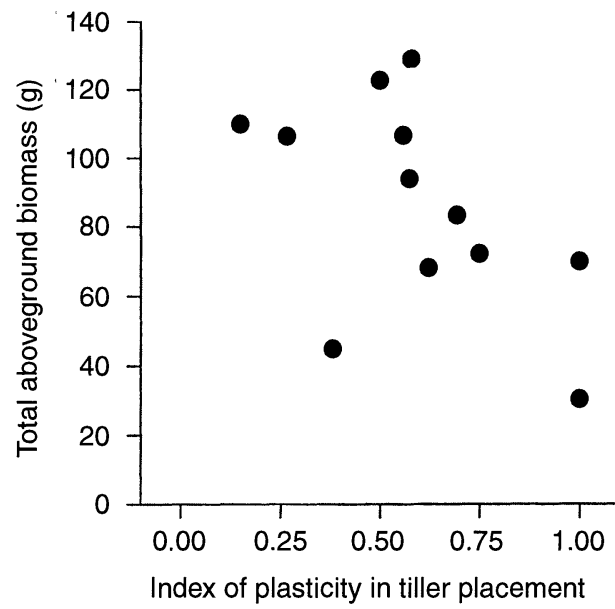

Fig. 6 Total above-ground biomass for each genet in plots with high-nutrient destination cells, and index of plasticity in tiller placement (for high-nutrient origin only, see text). A linear regression of above-ground biomass (untransformed) as a function of index of plasticity in tiller placement, showed no significant relationship. Because of missing values, only 12 of 14 genets are represented.

because, although plasticity in ramet placement by means of spacer lengths is relatively common in response to light patches, few studies have shown such responses to nutrient patches (de Kroon \& Hutchings 1995).

The proportion of tillers that were phalanx responded primarily to local patch quality; nutrient status of the origin cell was not significant. In contrast, the number of all tillers in destination cells, which can be a passive response to greater growth, responded strongly to nutrient status of both the destination cell and the origin cell. The growth response to origin implies substantial clonal integration, yet the response of spacer lengths was to local patch quality, which is necessary if preferential placement of ramets in favourable patches is to be achieved by means of spacer plasticity (Hutchings 1988; de Kroon \&
Schieving 1990). Other studies have shown similar morphological responses to local patch quality rather than averaging of habitats, even when substantial physiological integration existed (Slade \& Hutchings 1987b; Turkington, Sackville Hamilton \& Gliddon 1991; Evans 1992; Hutchings \& Price 1993). Levels to which local morphological responses are modified by physiological integration can differ between species and may be adaptive (Dong 1995). Rather than diminishing morphological responses to local patch quality, connection to ramets in favourable patches resulted in a greater response to unfavourable patches (greater spacer lengths) in Hydrocotyle bonariensis (Evans 1992) and Trifolium repens (Turkington \& Klein 1991).

\section{BENEFITS OF CLONAL FORAGING VERSUS ROOT PROLIFERATION}

Root invasion was an important second mechanism of accessing patches in the rhizomatous grass, while the bunchgrass accessed patches as effectively by root invasion alone. This resulted in similar above-ground biomass responses of the two taxa to high-nutrient destination cells. Exploitation of nutrient patches by root proliferation is effective in increasing whole-plant growth in other species (Drew \& Saker 1975). Glechoma hederacea effectively exploited nutrient patches by root proliferation from ramets located in highnutrient zones (Birch \& Hutchings 1994). Although one taxon is rhizomatous and the other is caespitose, and Snake River typically occurs on drier sites where the importance of temporal variation in resource availability may be greater (e.g. Goldberg \& Novoplansky 1997), spatial patchiness of nutrients at the scale used in this experiment was effectively exploited by both taxa.

Although thickspike's range of tiller lengths 
allowed it to concentrate tillers in high-nutrient patches of the size used in this experiment, any benefits this may have conferred on above-ground biomass of the clone may have been overshadowed by the benefits from root growth. Clonal foraging might concentrate tillers in high-nutrient patches even more effectively at other scales of patchiness. The ability of Glechoma hederacea to exploit patches of soil nutrients was strongly dependent on the size of the patches relative to the size scale of stolon growth (Wijesinghe \& Hutchings 1997). Also, clonal foraging may be more important relative to root growth in species where the relative scales of rhizome growth and root growth enable rhizomes to access patches that roots cannot (e.g. McIntyre 1967; Lovett Doust 1987; Evans 1992).

\section{GENETIC DIFFERENCES IN AND ADVANTAGES OF CLONAL FORAGING}

Although the importance of root foraging could have contibuted to the lack of a significant relationship between biomass and genetic variation in degree of plasticity in ramet placement, finding a significant relationship was unlikely because genets did not differ significantly in degree of plasticity in ramet placement. Much inherent variation in plant morphology is not plastic in response to environmental conditions (e.g. endogenous branching patterns; de Kroon et al. 1994). This non-plastic variation may exceed variation that is plastic in response to patch conditions and thus obscure the plastic response. The variation in tiller placement in this experiment was considerable. Non-plastic variation may have obscured genetic differences in degree of plasticity in response to nutrinet patches.

Some clonal plants can benefit from heterogeneous environments compared to homogeneous ones (Birch \& Hutchings 1994). Many mechanisms can be involved. Plastic responses of roots and orthotropic shoots are often more common and may be more advantageous than foraging responses involving ramet placement (de Kroon \& Hutchings 1995). These plastic responses are often beneficial under the same or similar conditions as clonal foraging, and plants may often possess these mechanisms along with clonal foraging (as apparently was the case with root proliferation in our experiment). Furthermore, plastic responses involving different plant parts may arise from similar mechanisms (Voesenek \& Blom 1996). The benefit of clonal foraging may therefore be manifested mainly in its interaction with these other plastic responses, or it may be maintained by natural selection, because it is mechanistically associated with other responses that are more beneficial. Simulation models of clonal growth suggest that the benefit of any one mechanism of ramet placement acting alone is usually very limited (Oborny 1994). Morphological plasticity (of various plant parts) may also play a secondary role alongside other traits of clonal plants.
Although increased ramet production in highresource patches is a passive growth response, it can contribute more than plasticity in spacer lengths to concentrating ramets in high-resource patches (Cain, Dudle \& Evans 1996). Glechoma hederacea produced greater biomass when nutrients were patchy than when they were uniform, primarily because ramets in high-nutrient patches allocated much more resources to root production than ramets in low-nutrient areas did, although a weak ramet placement response to nutrient patches also occurred (Birch \& Hutchings 1994). Clones of Potentilla (P. reptans and P. anserina) produced more biomass in patchy than in uniform light environments (Stuefer et al. 1994) and nutrient environments ( $P$. simplex; Wijesinghe \& Handel 1994) as a result of clonal integration and resource sharing. In clonal plants, plasticity in ramet placement can act in concert not only with plastic responses of other plant parts, but also with physiological plasticities, and differences in physiological integration and resource allocation. Because of interactions between many traits, identifying the importance of any one trait may be difficult.

\section{Acknowledgements}

We thank Utah State University for providing the research site and other resources. This research was supported by NSF grants BSR-8705492 and DEB9208212. Comments of Elisabeth Huber-Sannwald and Hans de Kroon were appreciated.

\section{References}

Ballaré, C.L., Scopel, A.L. \& Sanchez, R.A. (1990) Far-red radiation reflected from adjacent leaves: an early signal of competition in plant canopies. Science, 247, 329-332.

Bell, G. \& Lechowicz, M.J. (1994) Spatial heterogeneity at small scales and how plants respond to it. Exploitation of Environmental Heterogeneity by Plants, Ecophysiological Processes Above- and Belowground (eds M. M. Caldwell \& R. W. Pearcy), pp. 391-414. Academic Press, New York.

Birch, C.P.D. \& Hutchings, M.J. (1994) Exploitation of patchily distributed soil resources by the clonal herb Glechoma hederacea. Journal of Ecology, 82, 653-664.

Bohm, W. (1979) Methods of studying root systems. Ecological Studies, Analysis and Synthesis (eds W. D. Billings, F. Golley, O. L. Lange \& J. S. Olson), SpringerVerlag, New York.

Bradshaw, A.D. (1965) Evolutionary significance of phenotypic plasticity in plants. Advances in Genetics, 13, 115155.

Cain, M.L. (1994) Consequences of foraging in clonal plant species. Ecology, 75, 933-944.

Cain, M.L., Dudle, D.A. \& Evans, J.P. (1996) Spatial models of foraging in clonal plant species. American Journal of Botany, 83, 76-85.

Caldwell, M.M. \& Virginia, R.A. (1989) Root systems. Plant Physiological Ecology, Field Methods and Instrumentation (eds R. W. Pearcy, J. R. Ehleringer, H. A. Mooney \& P. W. Rundel), pp. 367-398. Chapman and Hall, London and New York. 


\section{L.D. Humphrey \& D.A. Pyke}

Cheplick, G.P. (1995) Genotypic variation and plasticity of clonal growth in relation to nutrient availability in Amphibromus scabrivalis. Journal of Ecology, 83, 459468.

Cook, R.E. (1983) Clonal plant populations. American Scientist, 71, 244-253.

Crick, J.C. \& Grime, J.P. (1987) Morphological plasticity and mineral nutrient capture in two herbaceous species of contrasted ecology. New Phytologist, 107, 403-414.

Dong, M. (1995) Morphological responses to local light conditions in clonal herbs from contrasting habitats, and their modification due to physiological integration. Oecologia, 101, 282-288.

Drew, M.C. \& Saker, L.R. (1975) Nutrient supply and the growth of the seminal root system in barley. II. Localized, compensatory increases in lateral root growth and rates of nitrate uptake when nitrate supply is restricted to only part of the root system. Journal of Experimental Botany, 26, 79-90.

Eissenstat, D.M. \& Caldwell, M.M. (1988) Seasonal timing of root growth in favorable microsites. Ecology, 69, 870873.

Evans, J.P. (1992) The effect of local resource availability and clonal integration on ramet functional morphology in Hydrocotyle bonariensis. Oecologia, 89, 265-276.

Goldberg, D.E. \& Novoplansky, A. (1997) On the relative importance of competition in unproductive environments. Journal of Ecology, 85, 409-418.

Hillman, J.R. (1984) Apical dominance. Advanced Plant Physiology (ed. M. B. Wilkins), pp. 127-148. Pitman, Bath, UK

Hume, L. \& Cavers, P.B. (1982) Geographic variation in a widespread perennial weed, Rumex crispus. The relative amounts of genetic and environmentally induced variation among populations. Canadian Journal of Botany, 60, 1928-1937.

Hutchings, M.J. (1988) Differential foraging for resources and structural plasticity in plants. Trends in Ecology and Evolution, 3, 200-204.

Hutchings, M.J. \& de Kroon, H. (1994) Foraging in plants: the role of morphological plasticity in resource acquisition. Advances in Ecological Research, 25, 159-238.

Hutchings, M.J. \& Mogie, M. (1990) The spatial structure of clonal plants: control and consequences. Clonal Growth in Plants: Regulation and Function (eds J. van Groenendael \& H. de Kroon), pp. 57-76. SPB Academic Publishing, The Hague, the Netherlands.

Hutchings, M.J. \& Price, E.A.C. (1993) Does physiological integration enable clonal herbs to integrate the effects of environmental heterogeneity? Plant Species Biology, 8, 95-105.

Jackson, R.B. \& Caldwell, M.M. (1989) The timing and degree of root proliferation in fertile-soil microsites for three cold-desert perennials. Oecologia, 81, 149-153.

Jackson, R.B. \& Caldwell, M.M. (1991) Kinetic response of Pseudoroegneria roots to localized soil enrichment. Plant and Soil, 138, 231-238.

Jackson, R.B. \& Caldwell, M.M. (1993) The scale of nutrient heterogeneity around individual plants and its quantification with geostatistics. Ecology, 74, 612-614.

Jackson, R.B. \& Caldwell, M.M. (1996) Integrating resource heterogeneity and plant plasticity: modelling nitrate and phosphate uptake in a patchy soil environment. Journal of Ecology, 84, 891-903.

Jackson, R.B., Manwaring, J.H. \& Caldwell, M.M. (1990) Rapid physiological adjustment of roots to localized soil enrichment. Nature, 344, 58-60.

(C) 1997 British

Ecological Society, Journal of Ecology, 85, 601-610
Jain, S.K. (1978) Inheritance of phenotypic plasticity in soft chess, Bromus mollis, L. (Graminae). Experientia, 34, 835-836.

Kelly, C.K. (1990) Plant foraging: a marginal value model and coiling response in Cuscuta subinclusa. Ecology, 71, 1916-1925.

de Kroon, H. \& Hutchings, M.J. (1995) Morphological plasticity in clonal plants: the foraging concept reconsidered. Journal of Ecology, 83, 143-152.

de Kroon, H. \& Knops, J. (1990) Habitat exploration through morphological plasticity in two chalk grassland perennials. Oikos, 59, 39-49.

de Kroon, H. \& Schieving, F. (1990) Resource partitioning in relation to clonal growth strategy. Clonal Growth in Plants: Regulation and Function (eds J. van Groenendael \& H. de Kroon), pp. 113-130. SPB Academic Publishing, The Hague, the Netherlands.

de Kroon, H., Stuefer, J.F., Dong, M. \& During, H.J. (1994) On plastic and non-plastic variation in clonal plant morphology and its ecological significance. Folia Geobotanica and Phytotaxonomica, 29, 123-138.

Lovett Doust, L. (1981) Population dynamics and local specialization in a clonal perennial (Ranunculus repens). I. The dynamics of ramets in contrastng habitats. Journal of Ecology, 69, 743-755.

Lovett Doust, L. (1987) Population dynamics and local specialization in a clonal perennial (Ranunculus repens). III. Responses to light and nutrient supply. Journal of Ecology, 75, 555-568.

McIntyre, G.I. (1967) Environmental control of bud and rhizome development in the seedling of Agropyron repens L. Beauv. Canadian Journal of Botany, 45, 13151326.

Oborny, B. (1994) Growth rules in plants and environmental predictability - a simulation study. Journal of Ecology, 82, 341-351.

Pigliucci, M. (1996) How organisms respond to environmental changes: from phenotypes to molecules (and vice versa). Trends in Ecology and Evolution, 11, 168 173.

Pyke, G.H. (1978) Optimal foraging: movement patterns of bumblebees between inflorescences. Theoretical Population Biology, 13, 721-798.

Salisbury, F.B. \& Marinos, N.G. (1985) The ecological role of plant growth substances. Encyclopedia of Plant Physiology, New Series Vol. 11 (eds R. P. Pharis \& D. M. Reid), pp. 707-766. Springer-Verlag, Berlin.

Salzman, A.G. (1985) Habitat selection in a clonal plant. Science, 228, 603-604.

SAS Institute (1988) SAS/STAT User's Guide, Release 6.03. SAS Institute, Inc., Cary, North Carolina.

Schlichting, C.D. (1986) The evolution of phenotypic plasticity in plants. Annual Review of Ecology and Systematics, 17, 667-693

Schmitt, J., McCormac, A.C. \& Smith, H. (1995) A test of the adaptive plasticity hypothesis using transgenic and mutant plants disabled in phytochrome-mediated elongation responses to neighbours. American Naturalist, 146, 937-953.

Slade, A.J. \& Hutchings, M.J. (1987a) The effects of nutrient availability on foraging in the clonal herb Glechoma hederacea. Journal of Ecology, 75, 95-112.

Slade, A.J. \& Hutchings, M.J. (1987b) Clonal integration and plasticity in foraging behaviour in Glechoma hederacea. Journal of Ecology, 75, 1023-1036.

Smucker, A.J.M., McBurney, S.L. \& Srivastava, A.K. (1982) Quantitative separation of roots from compacted soil profiles by the hydropneumatic elutriation system. Agronomy Journal, 74, 500-503.

Stuefer, J.F., During, H.J. \& de Kroon, H. (1994) High benefits of clonal integration in two stoloniferous species, in response to heterogeneous light environments. Journal of Ecology, 82, 511-518.

Sutherland, W.J. \& Stillman, R.A. (1988) The foraging tactics of plants. Oikos, 52, 239-244. 

and patchy soil nutrients
Taylor, D.R. \& Aarssen, L.W. (1988) An interpretation of phenotypic plasticity in Agropyron repens (Graminae). American Journal of Botany, 75, 401-413.

Thompson, J.D. (1991) Phenotypic plasticity as a component of evolutionary change. Trends in Ecology and Evolution, 6, 246-249.

Thompson, J.D., McNeilly, T. \& Gray, A.J. (1991) Population variation in Spartina anglica C.E. Hubbard. III. Response to substrate variation in a glasshouse experiment. New Phytologist, 117, 141-152.

Turkington, R. \& Klein, E. (1991) Integration among ramets of Trifolium repens. Canadian Journal of Botany, $\mathbf{6 9}$, 226-228.

Turkington, R., Sackville Hamilton, R. \& Gliddon, C. (1991) Within-population variation in localized and integrated responses of Trifolium repens to biotically patchy environments. Oecologia, 86, 183-192.

Voesenek, L.A.C.J. \& Blom, C.W.P.M. (1996) Plants and hormones: an ecophysiological view on timing and plasticity. Journal of Ecology, 84, 111-119.

Wijesinghe, D.K. \& Handel, S.N. (1994) Advanatges of clonal growth in heterogeneous habitats: an experiment with Potentilla simplex. Journal of Ecology, 82, 495-502.

Wijesinghe, D.K \& Hutchings, M.J. (1997) The effects of spatial scale of environmental heterogeneity on the growth of a clonal plant: an experimental study with Glechoma hederacea. Journal of Ecology, 85, 17-28.

Received 9 March 1996

revision accepted 7 April 1997 